\title{
Pharmacological actions of a novel NO-independent guanylyl cyclase stimulator, BAY 41-8543: in vitro studies
}

\author{
*,1 Johannes-Peter Stasch, ${ }^{2}$ Cristina Alonso-Alija, ${ }^{3}$ Heiner Apeler, ${ }^{1}$ Klaus Dembowsky, \\ ${ }^{2}$ Achim Feurer, ${ }^{3}$ Torsten Minuth, ${ }^{1}$ Elisabeth Perzborn, ${ }^{1}$ Matthias Schramm \& ${ }^{2}$ Alexander Straub
}

${ }^{1}$ Institute of Cardiovascular Research, Bayer AG, Pharma Research Center, Wuppertal, Germany; ${ }^{2}$ Institute of Medicinal Chemistry, Bayer AG, Pharma Research Center, Wuppertal, Germany and ${ }^{3}$ Institute of Biotechnology, Bayer AG, Pharma Research Center, Wuppertal, Germany

1 BAY 41-8543 is a novel, highly specific and so far the most potent NO-independent stimulator of sGC. Here we report the effects of BAY 41-8543 on the isolated enzyme, endothelial cells, platelets, isolated vessels and Langendorff heart preparation.

2 BAY 41-8543 stimulates the recombinant sGC concentration-dependently from $0.0001 \mu \mathrm{M}$ to $100 \mu \mathrm{M}$ up to 92-fold. In combination, BAY 41-8543 and NO have synergistic effects over a wide range of concentrations. Similar results are shown in implying that BAY 41-8543 stimulates the sGC directly and furthermore makes the enzyme more sensitive to its endogenous activator NO.

3 In vitro, BAY 41-8543 is a potent relaxing agent of aortas, saphenous arteries, coronary arteries and veins with $\mathrm{IC}_{50}$-values in the $\mathrm{nM}$ range.

4 In the rat heart Langendorff preparation, BAY 41-8543 potently reduces coronary perfusion pressure from $10^{-9}$ to $10^{-6} \mathrm{~g} \mathrm{ml}^{-1}$ without any effect on left ventricular pressure and heart rate.

5 BAY 41-8543 is effective even under nitrate tolerance conditions proved by the same vasorelaxing effect on aortic rings taken either from normal or nitrate-tolerant rats.

6 BAY 41-8543 is a potent inhibitor of collagen-mediated aggregation in washed human platelets $\left(\mathrm{IC}_{50}=0.09 \mu \mathrm{M}\right)$. In plasma, BAY 41-8543 inhibits collagen-mediated aggregation better than ADPinduced aggregation, but has no effect on the thrombin pathway. BAY 41-8543 is also a potent direct stimulator of the cyclic GMP/PKG/VASP pathway in platelets and synergizes with NO over a wide range of concentrations.

7 These results suggest that BAY 41-8543 is on the one hand an invaluable tool for studying sGC signaling in vitro and on the other hand its unique profile may offer a novel approach for treating cardiovascular diseases.

British Journal of Pharmacology (2002) 135, 333-343

Keywords: Nitric oxide; soluble guanylyl cyclase; cyclic GMP; BAY 41-8543; ODQ; YC-1; VASP; endothelial cells; platelets; vasorelaxation

Abbreviations: CO, carbon monoxide; DEA/NO, 2-(N,N-diethylamino)-diazenolate-2-oxide; DMSO, dimethyl sulfoxide; GTN, glycerol trinitrate; HEPES, 4-(2-hydroxyethyl)-1-piperazineethanesulfonic acid; ISDN, isosorbide dinitrate; ODQ, 1H-(1,2,4)oxadiazole-(4,3-a)quinoxalin-1-one; PKG, cyclic GMP dependent protein kinase; PPIX, protoporphyrin IX; sGC, soluble guanylyl cyclase; SIN-1, 3-morpholinosydnonimine; VASP, vasodilatorstimulated phosphoprotein; YC-1, 3-(5'-Hydroxymethyl-2'-furyl)-1-benzylindazole

\section{Introduction}

Guanylyl cyclases (GTP pyrophosphate-lyase [cyclizing]; EC 4.6.1.2) catalyse the biosynthesis of cyclic GMP from GTP. While the membrane bound forms are monomers which are stimulated by the natriuretic peptides, the soluble guanylyl cyclases exist as heterodimers consisting of an $\alpha$ - and a $\beta$ subunit and contain a heme as a prosthetic group (Wedel \& Garbers, 1997). By formation of cyclic GMP as a second messenger, sGC plays an important role in smooth muscle cell relaxation (Lincoln, 1989), inhibition of platelet aggregation, retinal signal transduction (Moncada \& Higgs, 1995) and synaptic transmission (Zhuo \& Hawkins, 1995). The $\mathrm{sGC}$ is the intracellular receptor for the ubiquitous

*Author for correspondence; Institute of Cardiovascular Research, Bayer AG, Aprather Weg 18a, Q-42096 Wuppertal, Germany

E-mail: Johannes-Peter.Stasch.JS@ bayer-ag.de biological messenger NO (Moncada et al., 1991; Furchgott, 1999; Murad, 1999; Ignarro, 1999) and is also activated by the benzylindazole derivative YC-1 (Ko et al., 1994; Mülsch et al., 1997; Friebe et al., 1996; Hoenicka et al., 1999). In several studies, YC-1 was shown to inhibit platelet aggregation by elevation of cyclic GMP causing VASP phosphorylation (Wu et al., 1995; 1997; Ko et al., 1994; Friebe et al., 1998; Becker et al., 2000) and to relax precontracted aortic rings (Mülsch et al., 1997). Interestingly, in addition to the direct activation of the purified sGC by YC-1, an overadditive effect was observed by the combinations of YC-1 and NO (Friebe et al., 1996; Mülsch et al., 1997; Hoenicka et al., 1999; Becker et al., 1999; 2000). It was also shown that YC-1 is a heme-dependent but NO-independent stimulator of sGC (Hoenicka et al., 1999). 
Recently, we described the new sGC stimulator BAY 412272, with similar characteristics to YC-1, however, with a distinctly higher potency of about two orders of magnitude and no PDE inhibitory activity in contrast to YC-1 (Stasch et al., 2001; Straub et al., 2001). Thereby, the therapeutic potential of pure sGC stimulation could be verified for the first time by using this compound. Using BAY 41-2272 as representative of this new pharmacological principle, we synthesized the corresponding photoaffinity label, characterized it on the purified enzyme, labelled the highly purified sGC, and identified the cysteine 238 and cysteine 243 spanning region in the $\alpha_{1}$-subnunit of sGC as part of the target site for this new type of sGC stimulators. BAY41-2272 potently stimulates sGC through this site by a mechanism that is NO-independent. This results in antiplatelet activity and vasodilation (Stasch et al., 2001).

NO-independent stimulators of sGC are very desirable as both pharmacological tools to proof the NO/cyclic GMP pathway and as potential therapeutic agents. Organic nitrates like GTN or ISDN have been used for decades as a treatment for coronary heart disease. However, the major drawbacks of this therapy are the development of tolerance and the negligible antiplatelet effect (Parker, 1989). This obstacle could now be overcome by the discovery of potent and specific NO-independent sGC stimulators.

In the search for NO-independent sGC stimulators, we selected BAY 41-8543, a close chemical analogue of BAY 412272 , as the most promising compound with respect to potency, specificity as well as oral activity out of a series of around two thousand synthesized derivatives (Straub et al., 1998; 2001; Stasch et al., 2002). We report herein the in vitro pharmacology of this promisingly novel, highly specific and potent NO-independent sGC stimulator, BAY 41-8543 (Figure 1).

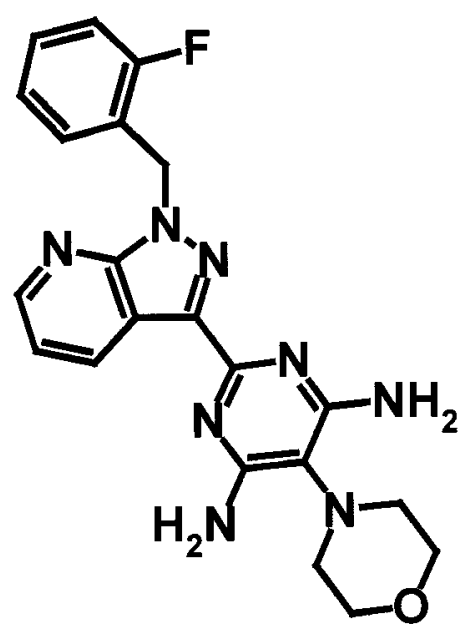

\section{BAY 41-8543}

Figure 1 BAY 41-8543, 2-[1-[(2-fluorophenyl)methyl]-1H-pyrazolo[3,4-b]pyridin-3-yl]-5(4-morpholinyl)-4,6-pyrimidinediamine.

\section{Methods}

\section{Substances and solutions}

BAY 41-8543 (2-[1-[(2-fluorophenyl)methyl]-1H-pyrazolo[3,4b]pyridin-3-yl]-5(4-morpholinyl)-4,6-pyrimidinediamine) was synthesized as described (Straub et al., 1998). $\alpha\left[{ }^{32} \mathrm{P}\right]-$ GTP was obtained from NEN-DuPont (Dreieich, Germany). All cell culture media and supplements were from Life Technologies (Eggenstein, Germany). Amphotericin B, streptomycin and penicillin were obtained from Secomed (Berlin, Germany). ODQ (1H-(1,2,4)-Oxadiazolo-(4,3a)-6-bromoquinoxazin-1one) was obtained from Tocris Cookson (Bristol, U.K.) and $10 \mathrm{~mm}$ stock solutions were prepared in DMSO. DEA/NO was obtained from Alexis (San Diego, CA, U.S.A.) and diluted freshly for each experiment on ice in $0.01 \mathrm{M} \mathrm{NaOH}$. ISDN was used as TD Spray Iso Mack ${ }^{\circledR}$ from Heinrich Mack (Illertissen, Germany) containing $100 \mathrm{mg}$ ISDN/ml. Collagen was obtained from Hormon-Chemie (Horm ${ }^{\mathbb{R}}$; München), and TRAP-6 from Bachem (Bubendorf, Switzerland). Phenylephrine was used as $10 \%$ drug preparation Neosynephrin-POS ${ }^{\circledR}$ from Ursapharm (Saarbrücken, Germany). U-46619 was used as $10 \mathrm{mg} / \mathrm{ml}$ drug preparation from Cayman Chemical (Ann Arbor, MI, U.S.A.). Dilution series of BAY 41-8543, SIN1 (Alexis, San Diego, CA, U.S.A.) and SNP (Fluka Chemicals, Buchs, Switzerland) were prepared in DMSO, the final organ bath concentration of DMSO being always $0.1 \%$. GTN was obtained from Merck (Darmstadt, Germany) as solution containing 1\% GTN; further dilutions were performed with DMSO. All other biochemicals were of the highest purity available and were purchased from Merck (Darmstadt, Germany), Roche Diagnostics (Mannheim, Germany) and Sigma (Deisenhofen, Germany).

\section{Rabbit aorta and saphenous artery}

Chinchilla rabbits of either sex (about $2-3 \mathrm{~kg}$ ) were sacrificed by an overdose of thiopental. The aorta and saphenous arteries were dissected and aortic rings $(1.5 \mathrm{~mm}$ width) and saphenous artery rings (3 $\mathrm{mm}$ width) were suspended under an initial tension of approximately $4 \mathrm{~g}$ in $5 \mathrm{ml}$ organ baths containing Krebs-Henseleit solution (containing $0.001 \%$ BSA) at $37^{\circ} \mathrm{C}$. Contractions were measured isometrically with Statham UC2 strain gauges connected to a DAS1802HC data acquisition board (Keithley instruments, Germering, Germany). Rings were precontracted by $3 \times 10^{-8} \mathrm{~g} \mathrm{ml}^{-1}$ phenylephrine (submaximal contraction) four times. Each contraction was followed by a series of 16 washing cycles and a resting period of $28 \mathrm{~min}$. The test compounds were added to the organ baths at the beginning of the last resting period. The concentration of the test compounds was increased by a factor of 10 . Rings were subsequently contracted by phenylephrine $\left(3 \times 10^{-8} \mathrm{~g} \mathrm{ml}^{-1}\right)$. The intact endothelium was functionally tested by the presence of the relaxant response to acetylcholine $(0.5 \mu \mathrm{M})$.

\section{Porcine coronary artery}

Hearts from domestic pigs were obtained from a local slaughtery house. The left circumflex coronary artery was dissected and rings $(1.5 \mathrm{~mm}$ width) were suspended under an 
initial tension of approximately $4 \mathrm{~g}$ in $5 \mathrm{ml}$ organ baths. Contractions in response to adding $+50 \mathrm{~mm}$ potassium chloride to the bath solution were carried out multiple times every $45 \mathrm{~min}$. Each contraction was followed by a series of 11 washing cycles and a resting period of $30 \mathrm{~min}$. A tonic contraction was induced by $3 \times 10^{-8} \mathrm{~g} \mathrm{ml}^{-1} \mathrm{U} 46619$, leading to a submaximal contraction. The contraction was allowed to stabilize for $30 \mathrm{~min}$ before the test compounds were added to the organ bath in a cumulative manner.

\section{Canine femoral vein}

Femoral veins were dissected from dogs of either sex $(20-$ $30 \mathrm{~kg}$ ). (Harlan Winkelmann, Borchen, Germany). Rings (3$5 \mathrm{~mm}$ length) were mounted on stainless steel hooks of $0.3 \mathrm{~mm}$ width, suspended under an initial tension of approximately $2 \mathrm{~g}$ in $5 \mathrm{ml}$ organ baths. Rings were contracted by $10^{-6} \mathrm{~g} \mathrm{ml}^{-1}$ phenylephrine (submaximal contraction) multiple times every $45 \mathrm{~min}$. Each contraction was followed by a series of 11 washing cycles and a resting period of $30 \mathrm{~min}$. A tonic contraction was induced by $10^{-6} \mathrm{~g} \mathrm{ml}^{-1}$ phenylephrine. After 15-20 min the test compounds were added to the organ baths in a cumulative manner.

\section{$s G C$ assay}

The sGC was highly purified from a baculovirus/Sf9 expression system and enzyme activity was measured in the presence of $\mathrm{Mg}^{2+}$ as described (Hoenicka et al., 1999).

\section{Spectroscopic studies}

$\mathrm{UV} / \mathrm{V}$ is spectra were recorded from $300 \mathrm{~nm}$ to $650 \mathrm{~nm}$ on a DU 640 spectrophotometer (Beckman, Munich, Germany). NO was introduced via an aqueous solution of DEA/NO. A $100 \mathrm{mM}$ stock solution of BAY 41-8543 in DMSO was prepared and added in a final concentration of $10 \mu \mathrm{M}$, resulting in a final DMSO concentration of $0.1 \%$, not interfering with properties of the enzyme (Hoenicka et al., 1999).

\section{Preparation of human platelet-rich plasma}

Human venous blood was collected by forearm venopuncture from healthy volunteers into plastic vessels containing $3.8 \%$ $\left(\mathrm{W} \mathrm{v}^{-1}\right)$ sodium citrate $\left(1 / 10=\mathrm{v} \mathrm{v}^{-1}\right)$. The donors had not taken any medication during the last 10 days prior to the study. Platelet-rich plasma was obtained by immediate centrifugation at $130 \times g$ for $20 \mathrm{~min}$ at room temperature.

\section{Preparation of washed human platelets}

The washing procedure was performed as previously described (Becker et al., 1999). The final cell count of the washed platelet suspension was adjusted to about $3 \times 10^{-8}$ platelets $\mathrm{ml}^{-1}$. Calcium and magnesium were restored by the addition of $2 \mathrm{mM} \mathrm{CaCl}_{2}$ and $2 \mathrm{mM} \mathrm{MgCl}_{2}$.

\section{Measurement of platelet aggregation}

Platelet aggregation was measured according to the turbidimetric method of Born \& Gross (1963) with an aggregometer
(Carat, IDC, Langewiesen). In the cuvette, platelet rich plasma or washed platelets were pre-incubated for $10 \mathrm{~min}$ at $37^{\circ} \mathrm{C}$ after the addition of BAY $41-8543$ or the vehicle. Aggregation was induced by the addition of collagen, $U$ 46619, thrombin, TRAP-6, or ADP. The concentration of the agonists was individually adjusted to achieve maximal aggregation response. In platelet rich plasma the final concentrations of collagen, ADP and TRAP-6 were $0.5-$ $3 \mu \mathrm{g} \mathrm{ml}^{-1}, 4-10 \mu \mathrm{g} \mathrm{ml}^{-1}$ and $50 \mu \mathrm{g} \mathrm{ml}^{-1}$, respectively and in washed platelets for collagen, $\mathrm{U}$ 46619, TRAP-6 and thrombin they were $0.8-5 \mu \mathrm{g} \mathrm{ml}^{-1}, 0.5-1 \mu \mathrm{g} \mathrm{ml}^{-1}, 30-$ $50 \mu \mathrm{g} \mathrm{ml}^{-1}$ and $5-10 \mu \mathrm{g} \mathrm{ml}^{-1}$, respectively. In order to quantify the inhibitory effect, the maximal increase in light transmission was determined from the aggregation curve 5 min after the addition of the agonist. The effect of BAY 418543 was expressed as percentage inhibition of agonistinduced platelet aggregation compared to vehicle of six independent experiments.

\section{Analysis of VASP phosphorylation in washed platelets}

Two hundred $\mu \mathrm{l}$ platelet suspensions $\left(2 \times 10^{8} \mathrm{ml}^{-1}\right)$ were incubated with $100 \mu \mathrm{l}$ stimulator incubation buffer containing the different stimulator concentrations as indicated in the Results section for $3 \mathrm{~min}$ at $37^{\circ} \mathrm{C}$. The time dependency of BAY $41-8543(10 \mu \mathrm{M})$, SNP $(3 \mu \mathrm{M})$, and their combination was examined. The reaction was stopped by adding $100 \mu 1$ SDS-containing stop solution (200 mM Tris/ $\mathrm{HCl}, 15 \%$ $\left(\mathrm{v} \mathrm{v}^{-1}\right)$ glycerol, $6 \%\left(\mathrm{w} \mathrm{v}^{-1}\right)$ SDS and $0.0075 \%\left(\mathrm{w} \mathrm{v}^{-1}\right)$ bromphenol blue, $\mathrm{pH}$ 6.7) and boiling for $10 \mathrm{~min}$ at $95^{\circ} \mathrm{C}$. At the end of the incubation time $100 \mu \mathrm{l}$ solution were withdrawn for cyclic GMP determination and mixed with $100 \mu \mathrm{l}$ ice cold ethanol.

\section{Immunoblotting}

Samples were separated by $9 \%$ SDS-PAGE (Mini-PROTEAN II cell, Bio-Rad, München, Germany) using a modified Laemmli method (Laemmli, 1970). The protein bands were transferred to a nitrocellulose membrane (MiniPROTEAN II cell, Trans-Blot ${ }^{\circledR}$ Transfer Medium Pure Nitrocellulose Membrane $0.2 \mu \mathrm{m}$, Bio-Rad, München, Germany) (Towbin et al., 1979). Human platelets protein bands were labeled with a mouse monoclonal antibody (1:5000) directed against the 46- and 50-kDa species of human VASP (Alexis, San Diego, CA, U.S.A.). In a second set of blots, Ser $^{239}$ phosphorylated VASP in human platelets was detected with $0.5 \mu \mathrm{g} \mathrm{ml}^{-1}$ mouse monoclonal antibody (16C2) raised against the phosphorylation site $\operatorname{Ser}^{239}$ of VASP (Smolenski et al., 1998), which is the site preferred by PKG. A biotinylated anti-mouse IgG for monoclonal antibodies (Pierce, Rockford, U.S.A.) and a biotinylated anti-rabbit $\mathrm{IgG}$ for the polyclonal antiserum in combination with the avidin biotin peroxidase system (Vectastain ABC-Kit , Calbiochem, Bad Soden, Germany) and the Amersham Enhanced Chemoluminescense kit (ECL) (Amersham, U.K.) were used as detection systems. Blots were exposed to Amersham Hyperfilm ECL films (Amersham) and developed using AGFA Curix 60. Laser densitometric evaluations were performed using Molecular Dynamics Computing Densitometer in combination with the Molecular Dynamics Image Quant Software (Molecular Dynamics, Krefeld, Germany). 


\section{Determination of cyclic GMP}

Cyclic GMP was determined by a commercially available radioimmuno-assay kit cyclic GMP[ $\left.{ }^{125} \mathrm{I}\right]$ (IBL, Hamburg, Germany), as recently described (Becker et al., 1999).

\section{Endothelial cells}

Briefly, primary porcine aortic endothelial cells were cultured in Medium 199 with Earle's salts containing 25 mM HEPES, $10 \%$ heat inactivated FCS, $2.5 \mu \mathrm{g} \mathrm{ml}^{-1}$ amphotericin B, $100 \mathrm{U} \mathrm{ml}^{-1}$ penicillin and streptomycin, $0.25 \mathrm{mg} \mathrm{ml}^{-1}$ konamycin, and $0.05 \mathrm{mg} \mathrm{ml}^{-1}$ gentamycin and were maintained at $37^{\circ} \mathrm{C}$ in a humidified $95 \%$ air $-5 \% \mathrm{CO}_{2}$ incubator. The culture medium was changed every 3-4 days. Endothelial cells were harvested, washed with PBS and grown in 24-well plates. Confluence is reached after $3-4$ days. The assay and the determination of endothelial cyclic GMP formation were determined as previously described (Becker et al., 1999).

\section{Rat heart Langendorff preparation}

The hearts of Wistar rats $(200-250 \mathrm{~g})$ were perfused according to Langendorff at $37^{\circ} \mathrm{C}$ with a non-recirculating system. The perfusion medium was a filtered KrebsHenseleit solution containing $11 \mathrm{mmol}^{-1}$ glucose and $1.2 \mathrm{mmol} \mathrm{l}^{-1} \quad \mathrm{CaCl}_{2}$, equilibrated with $\mathrm{O}_{2}+\mathrm{CO}_{2}$ $(95 \%+5 \%)$, to give a $\mathrm{pH}$ of 7.4 and a $\mathrm{pO}_{2}$ of 650 to $700 \mathrm{mmHg}$. Perfusion was performed at a constant rate $\left(10 \mathrm{ml} \mathrm{min}{ }^{-1}\right)$. A latex balloon filled with saline and connected to a pressure transducer (Gould Statham, Oxnard, CA, U.S.A.) via a metal cannula was inserted into the left ventricular cavity to measure the isovolumetric contractions of the left ventricle. A second pressure transducer was connected to the aortic cannula in order to record the perfusion pressure. Drug solutions were infused into the aortic cannula at a rate of $1 \%$ of the total flow rate.

\section{Introduction of nitrate tolerance}

The skin of Wistar rats $(200-250 \mathrm{~g})$ was shaved between both scapulae. To induce nitrate tolerance, ISDN was applied percutaneously with a dose of approximately $150-250 \mathrm{mg}$ three times a day over a period of 3 days. Thereafter, the rats received an additional ISDN administration in the morning before sacrificing. The aorta was dissected and used for in vitro studies.

\section{Statistics}

Unless otherwise indicated the results shown represent means \pm s.e.mean from at least three independent experiments performed in duplicates. Differences were assessed by oneway ANOVA followed by Bonferoni test for comparison of means or by Student's test. $P<0.05$ was considered significant.

\section{Results}

We studied the stimulatory effects of BAY 41-8543 (Figure 1) and $\mathrm{NO}$ on the highly purified sGC and the blocking effects of the sGC inhibitor ODQ. The specific basal activity of the recombinant enzyme in this set of experiments was in the range of $109-185 \mathrm{nmol} \mathrm{mg}^{-1} \mathrm{~min}^{-1}$ with $\mathrm{Mg}^{2+}$ as cofactor. Stimulation by the various stimulators or combination of stimulators is expressed as multiples of stimulation versus basal specific activity. BAY 41-8543 concentration-dependently stimulated sGC 2- to 92-fold from $0.0001-100 \mu \mathrm{M}$ (Table 1).

In addition, we investigated the sGC stimulatory effects of BAY 41-8543 and the NO releasing drug SIN-1 and in combination in a separate experiment. In this set of studies, BAY41-8543 stimulated the enzyme maximally 72 -fold at $100 \mu \mathrm{M}$, whereas SIN-1 induced an increase in the activity of 69 -fold at a concentration of $10 \mu \mathrm{M}$. In combination, BAY 41-8543 and SIN-1 synergize over a wide range of concentrations. At the highest concentration of BAY 41$8543(100 \mu \mathrm{M})$ and SIN-1 $(10 \mu \mathrm{M})$, the specific activity of sGC was 232-fold above the baseline (Figure 2). Moreover, BAY 41-8543 shows the same synergism in combination with the NO-donor sodium nitroprusside (SNP). At $0.1 \mu \mathrm{M} \mathrm{SNP}$ and the highest concentration of BAY $41-8543(10 \mu \mathrm{M})$ the specific activity of sGC was 362 -fold above the baseline (Figure 3). This sGC stimulation induced by BAY 41-8543 could be completely blocked by the potent sGC inhibitor ODQ (Figure 3).

NO stimulates sGC via the formation of a nitrosyl-heme complex, implying that the prosthetic heme group of sGC is necessary for the stimulatory effect of NO. Removal of the heme group by the non-ionic detergent Tween-20 (0.5\%) leads to an NO-insensitive sGC without destruction of basal enzyme activity. As shown in Figure 4, BAY 41-8543 does not activate the heme-free enzyme. In addition, PPIX concentration-dependently stimulates the heme-free sGC and has a synergistic effect on sGC activity in combination with BAY 41-8543 as shown in Figure 4.

To determine whether BAY 41-8543 directly interacts with the prosthetic heme group, we recorded the UV-visual spectra of the purified recombinant $\mathrm{sGC}$ under unstimulated and stimulated conditions. NO elicited the characteristic shift of the Soret peak to lower wavelength, while the addition of BAY 41-8543 resulted in no change of the Soret band of either the non-stimulated $(431 \mathrm{nM})$ or NO-stimulated (398 nM) enzyme. Therefore, unlike NO, BAY 41-8543 probably does not bind to the heme moiety of sGC.

At concentrations from $0.1 \mu \mathrm{M}$ to $3 \mu \mathrm{M}$ BAY $41-8543$ induced a concentration-dependent cyclic GMP increase in endothelial cells from a basal level of $1.7 \pm 0.3 \mathrm{pmol}^{\mathrm{we}} \mathrm{ll}^{-1}$ to $34.5 \pm 3.7 \mathrm{pmol} \mathrm{well}^{-1}$ (Figure 5). Incubation of endothelial cells with SIN-1 from 0.3 to $30 \mu \mathrm{M}$ led to a maximal increase of $14.7 \pm 1.5 \mathrm{pmol}^{\text {well }}{ }^{-1}$. In combination, BAY 41-8543 and SIN-1 synergize over a wide range of concentrations. At the highest concentration of BAY 41-8543 $(3 \mu \mathrm{M})$ and SIN-1 $(30 \mu \mathrm{M})$ examined, the cyclic GMP level was $61.9 \pm 2.6 \mathrm{pmol}$ well $^{-1}$ (Figure 5). On the other hand, we excluded an effect of BAY 41-8543 on certain PDE isoforms. BAY 41-8543 does not inhibit the cyclic GMP specific PDE5 and PDE9 as well as the cyclic GMP metabolizing PDEs, PDE1 and PDE2. Up to concentrations of $10 \mathrm{mM}$, the inhibition for all isoenzymes was less than $10 \%$.

On stimulation of endothelial cells with bradykinin (30 nM) intracellular cyclic GMP increased from $0.24 \pm 0.04$ to $1.0 \pm 0.2 \mathrm{pmol}^{\mathrm{we}} \mathrm{ll}^{-1}$. In this study, 3 and $30 \mu \mathrm{M}$ BAY $41-$ 
Table 1 Stimulation of purified sGC by BAY 41-8543

$\begin{array}{ccc}\begin{array}{c}\text { Concentration } \\ (\mu \mathrm{M})\end{array} & \begin{array}{c}\text { Specific activity } \\ \left(\mathrm{nmol} \mathrm{mg}^{-1} \mathrm{~min}^{-1}\right)\end{array} & \begin{array}{c}\text { Stimulation } \\ (\text { fold })\end{array} \\ 0 & 151 \pm 20(9) & 1.0 \\ 0.0001 & 377 \pm 117(9)^{*} & 2.5 \\ 0.001 & 654 \pm 252(9)^{*} & 4.3 \\ 0.01 & 688 \pm 246(9)^{* *} & 4.6 \\ 0.1 & 2.183 \pm 733(9)^{* *} & 14.4 \\ 1 & 7.377 \pm 1549(9)^{* * *} & 48.8 \\ 10 & 11.910 \pm 1.993(9)^{* * *} & 78.8 \\ 100 & 13.886 \pm 3.732(5)^{* * *} & 91.9\end{array}$

The data presented represent means \pm s.e.mean, from nine to five respectively, independent experiments performed in duplicate $\left({ }^{*} P<0.05, * * P<0.01, * * * P<0.001\right)$.

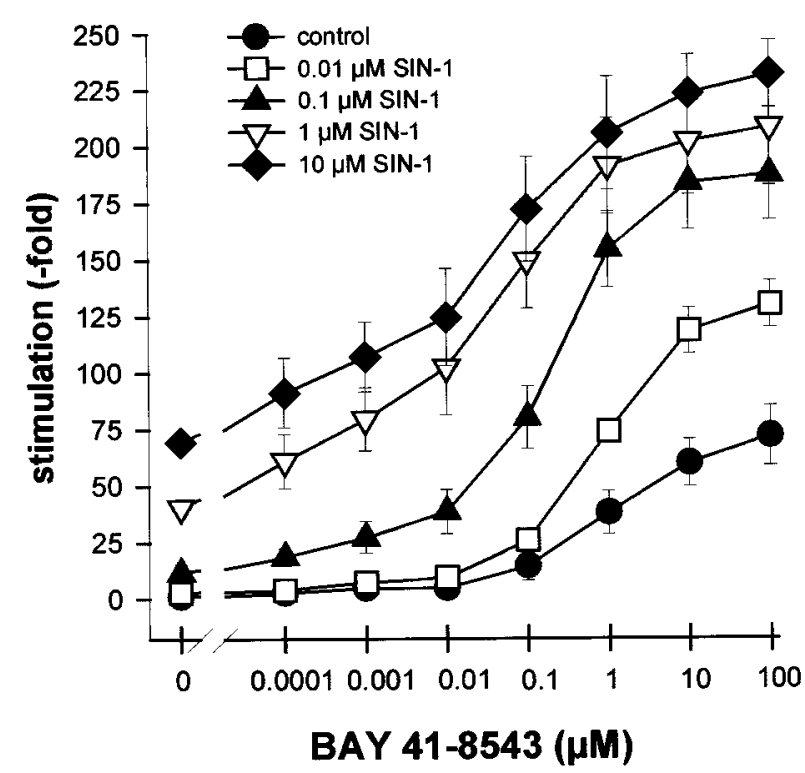

Figure 2 Stimulation of purified sGC by BAY 41-8543 (0.0001$100 \mu \mathrm{M})$ in the absence and presence of SIN-1 $(0.01-10 \mu \mathrm{M})$. The specific activity of sGC is expressed as $\mathrm{x}$-fold stimulation vs specific basal activity $\left(185 \pm 29 \mathrm{nmol} \mathrm{mg}{ }^{-1} \mathrm{~min}^{-1}\right.$ in the presence of $\left.\mathrm{Mg}^{2+}\right)$. The data presented represent means \pm s.e.mean from five independent experiments performed in duplicate.

8543 intracellular cyclic GMP levels increased to $29.6 \pm 5.1$ and $65.0 \pm 7.6 \mathrm{pmol}^{\mathrm{well}}{ }^{-1}$, respectively. In combination, BAY 41-8543 (3 and $30 \mu \mathrm{M})$ and bradykinin (30 nM) showed a potentiation of cyclic GMP increase in endothelial cells $\left(76.5 \pm 7.7\right.$ and $110.6 \pm 3.1$ pmol well $^{-1}$ ) (Figure 6).

The effect of BAY 41-8543 has been examined on the contraction of various isolated vessels (Figure 7). BAY 418543 concentration-dependently inhibited the phenylephrineinduced contractions of rabbit aorta, rabbit saphenous artery and canine femoral vein rings with $\mathrm{IC}_{50}$ values being 200, 110 and $200 \mathrm{nM}$, respectively. In addition, BAY 41-8543 concentration-dependently inhibited the U-46619-induced contraction of porcine coronary artery rings with $\mathrm{IC}_{50}$ being $11 \mathrm{nM}$. In general, BAY 41-8543 is distinctly more potent than SNP, SIN-1 and GTN, used as controls (Figure 7).

It was also studied whether the vasorelaxant effect of BAY 41-8543 is preserved under the nitrate tolerance conditions. For this purpose, the relaxant effect of BAY 41-8543 was examined on isolated aortic rings taken from normal and nitrate tolerant rats. Treatment with ISDN for 3 days resulted in a marked inhibition of GTN-mediated vasodilatation. GTN inhibited the phenylephrine-induced contraction with $\mathrm{IC}_{50}=0.6 \mu \mathrm{M}$ in control vessels and with $\mathrm{IC}_{50}=81 \mu \mathrm{M}$ in tolerant vessels, confirming the presence of nitrate tolerance. In contrast, BAY $41-8543$ is a potent inhibitor of phenylephrine-induced contractions both in normal and nitrate-tolerant aortic rings with $\mathrm{IC}_{50}$ values of 0.14 and $0.18 \mu \mathrm{M}$ (Figure 8).

In the rat heart Langendorff preparation, BAY 41-8543 reduces the coronary perfusion pressure in a concentrationdependent manner from 0.001 to $1 \mu \mathrm{g} \mathrm{ml}^{-1}$ with a maximal effect of about $70 \%$ at the highest concentration (Figure 9). No effect on left ventricular pressure and heart rate was observed.

The effects of the NO-independent, direct sGC stimulator BAY 41-8543 alone and in combination with SNP or DEA/ NO on two different phosphorylation sites of VASP (Ser ${ }^{157}$ and $\operatorname{Ser}^{239}$ ) were studied in human platelets using different specific antibodies. In human platelets we detected $\mathrm{Ser}^{157}$ phosphorylation by analysing the electrophoretic shift of VASP from the 46- to the 50-kDa species in SDS-PAGE (VASP Ser ${ }^{157}$ phosphorylation) using the monoclonal anti-VASP antibody, detecting both phosphorylated and nonphosphorylated VASP. To detect specifically VASP Ser $^{239}$ phosphorylation, we used a monoclonal antibody (16C2) specifically directed against the Ser $^{239}$ phosphorylated VASP.

Both types of sGC stimulator, BAY 41-8543 and the NO donors SNP and DEA/NO showed a concentration-dependent shift of VASP from the 46- to the $50-\mathrm{kDa}$ species in human platelets (Figure 10a; Table 2A) and a concentrationdependent increase in VASP $\operatorname{Ser}^{239}$ phosphorylation (Figure 10b). Furthermore, when the two stimulator types were combined, synergy was observed on VASP phosphorylation both at VASP $\operatorname{Ser}^{157}$ and $\operatorname{Ser}^{239}$ in human platelets (Figure 10a,b; Table 2A).

To compare the extent of VASP phosphorylation with the activity of platelet sGC, we determined the cyclic GMP responses in human platelets upon stimulation with both types of stimulator and their combinations. We detected with BAY 41-8543 $(30 \mu \mathrm{M})$ a 26.0 -fold increase in cyclic GMP levels in human platelets, with SNP $(30 \mu \mathrm{M})$ a 12.6-fold increase and with DEA/NO $(30 \mu \mathrm{M})$ a 40.1 -fold increase after 3 min of incubation (Table 2B). In addition, BAY 41-8543 in concentrations which showed only small effects on cyclic GMP levels by itself $(0.1 \mu \mathrm{M}$ : 1.7 -fold and $0.3 \mu \mathrm{M}$ : 2.6 -fold), induced a dramatic increase in cyclic GMP levels of 294-fold and 471-fold, respectively when applied in combination with SNP $(30 \mu \mathrm{M})$ (Table 2B). Comparable results were achieved with the combination of BAY 41-8543 and DEA/NO (Table 2A).

In an in vitro assay, BAY 41-8543 produced a concentration-related inhibition of platelet aggregation induced by various agonists in human platelet rich plasma and in washed platelets resuspended in buffer. The $\mathrm{IC}_{50}$ value of BAY 418543 for inhibition of collagen-induced platelet aggregation was $0.09 \mu \mathrm{M}$ in washed platelets and $5.7 \mu \mathrm{M}$ in plasma. $\mathrm{U} 46619$, a thromboxane $\mathrm{A}_{2}$ mimic, was studied in washed platelets: aggregation induced by $\mathrm{U} 46619$ was inhibited by BAY 41-8543 with an $\mathrm{IC}_{50}$ of $0.76 \mu \mathrm{M}$. The $\mathrm{IC}_{50}$ of BAY 418543 on ADP-induced aggregation in plasma was $12 \mu \mathrm{M}$. Washed platelets did not aggregate to ADP. Aggregation 


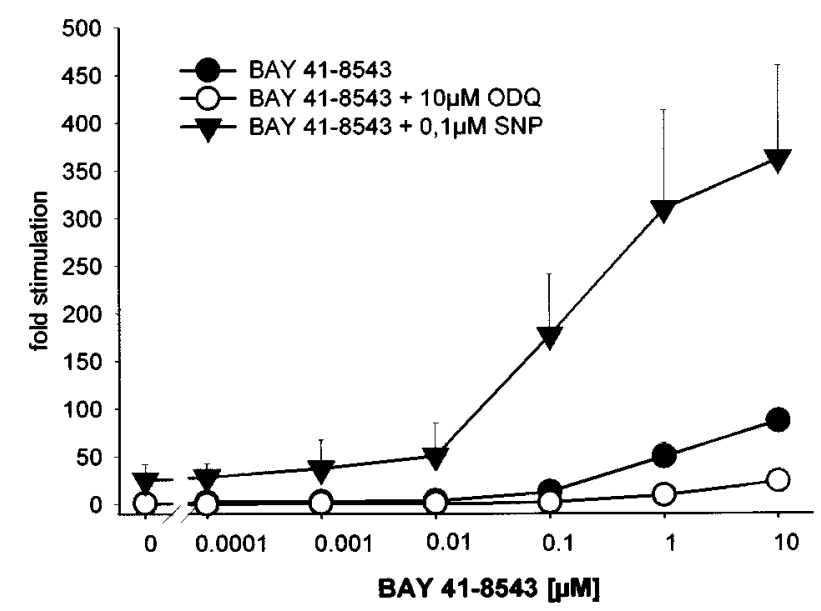

Figure 3 Stimulation of purified sGC by BAY 41-8543 in the presence of SNP $(0.1 \mu \mathrm{M})$ or ODQ $(10 \mu \mathrm{M})$. The specific activity of sGC is expressed as $\mathrm{x}$-fold stimulation vs specific basal activity $\left(109 \pm 10 \mathrm{nmol} \mathrm{mg} \mathrm{min}^{-1}\right.$ in the presence of $\left.\mathrm{Mg}^{2+}\right)$. The data presented represent means \pm s.e.mean, from four independent experiments performed in duplicate.

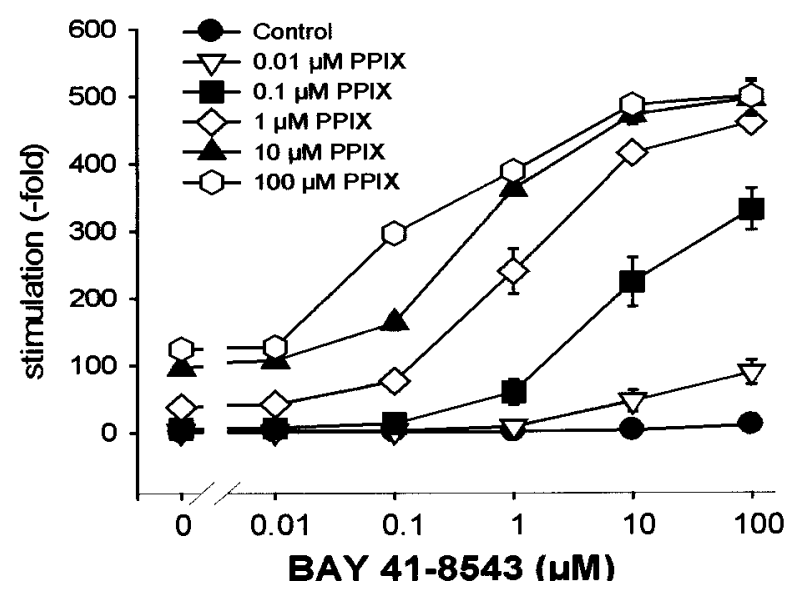

Figure 4 Stimulation of heme-free sGC by BAY 41-8543 (0.01$100 \mu \mathrm{M})$ in the absence and presence of protoporphyrin IX $(0.01-$ $100 \mu \mathrm{M})$. The specific activity of $\mathrm{sGC}$ is expressed as $\mathrm{x}$-fold stimulation vs specific basal activity $\left(89.9 \pm 4.6 \mathrm{nmol} \mathrm{mg}{ }^{-1} \mathrm{~min}^{-1}\right.$ in the presence of $\mathrm{Mg}^{2+}$ ). The data presented represent the means \pm s.e.mean from three independent experiments performed in duplicate.

induced by TRAP-6, a synthetic thrombin receptor agonist, was not reduced by BAY 41-8543 at concentrations up to $24 \mu \mathrm{M}$ in plasma and only weakly inhibited in washed platelets resulting in an $\mathrm{IC}_{50}$ of $7 \mu \mathrm{M}$. Thrombin-mediated aggregation also was only weakly affected by BAY 41-8543 with an $\mathrm{IC}_{50}$ of $17 \mu \mathrm{M}$ in washed platelets.

\section{Discussion}

Searching for NO-independent sGC stimulators, a series of potent pyrazolopyridine derivatives was selected out of around 2000 new synthesized substances (Straub et al., 1998). We used the indazole derivative YC-1 (Ko et al.,

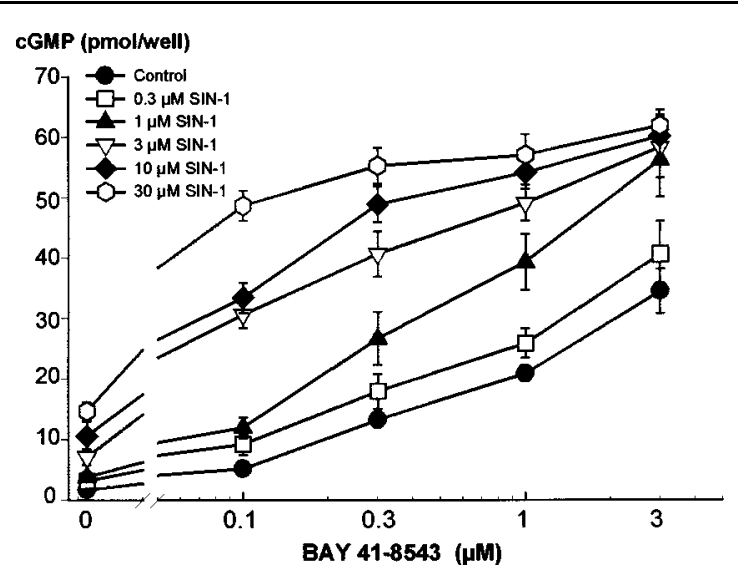

Figure 5 Stimulation of cyclic GMP increase in endothelial cells by BAY 41-8543 $(0.1-3 \mu \mathrm{M})$ in the absence and presence of SIN-1 $(0.3-$ $30 \mu \mathrm{M})$. The data presented represent means \pm s.e.mean, from four independent experiments performed in duplicate.

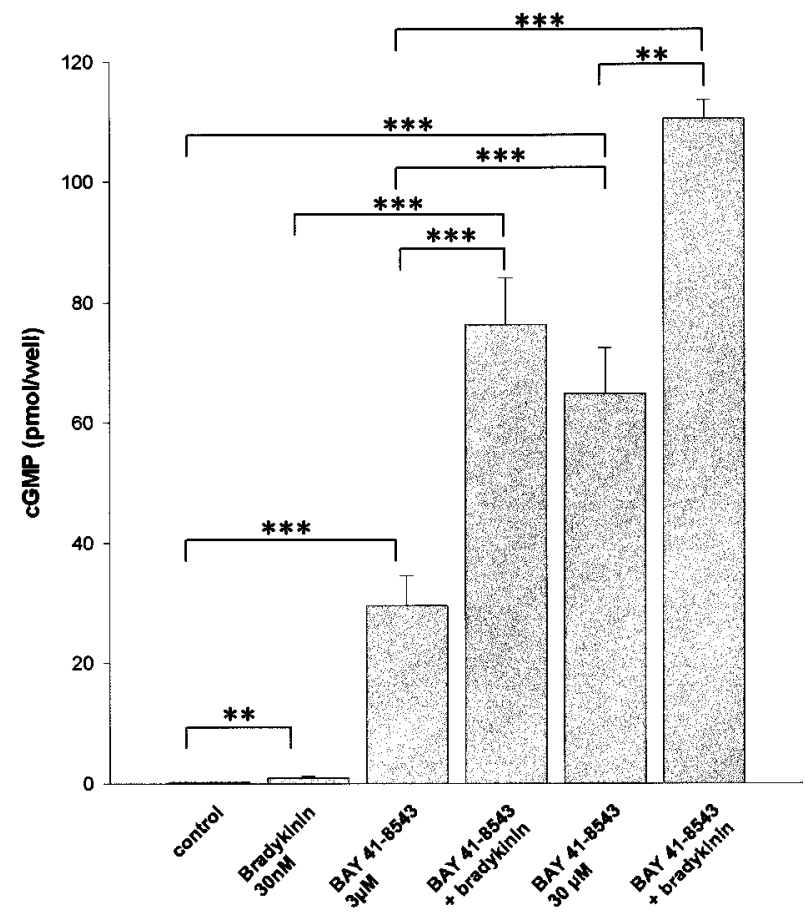

Figure 6 Stimulation of cyclic GMP increase in endothelial cells by BAY $41-8543$ (3 and $30 \mu \mathrm{M}$ ) in the absence and presence of endogenous NO released by bradykinin $(30 \mathrm{~nm})$. Incubation time for BAY 41-8543 was $10 \mathrm{~min}$ and for bradykinin $1 \mathrm{~min}$. The data presented represent means \pm s.e.mean, from six independent experiments performed in duplicate $(* * P<0.005 ; * * * P<0.001)$.

1994; Wu et al., 1995) as a chemical lead structure and identified BAY 41-8543 as the most promising compound. BAY 41-8543 is exceptionally potent in different in vitro systems as described in this paper as well as in vivo (Stasch et al., 2002). This compound is a close analogue of the recently published sGC stimulator BAY41-2272, however, BAY 418543 is about 3 -fold more potent in vivo after oral administration than BAY41-2272 (Stasch et al., 2001, 2002; Straub et al., 2001). This efficacy clearly differentiates these 

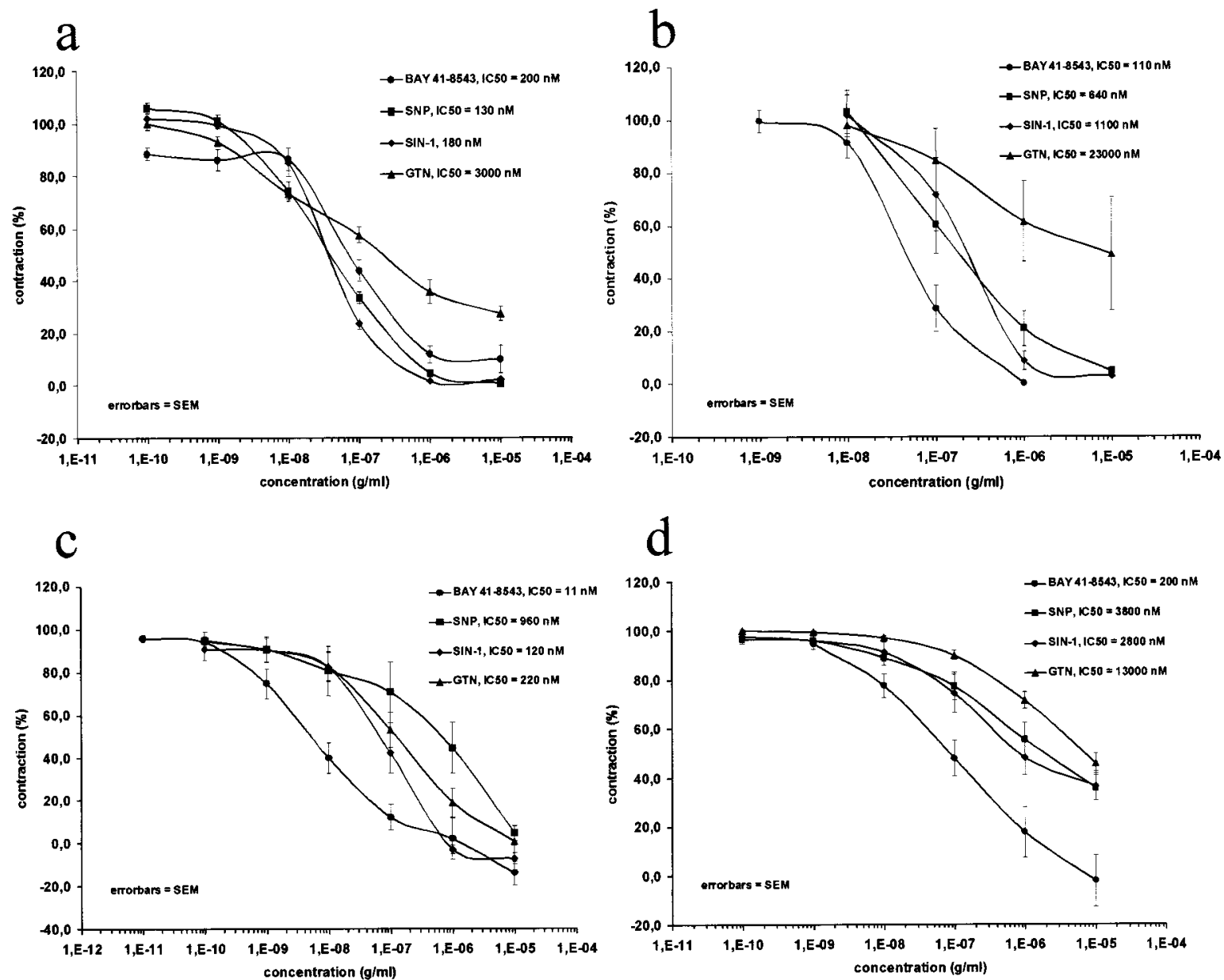

Figure 7 Vasorelaxing effects of BAY 41-8543, SNP, SIN-1 on isolated vessels. (a) Phenylephrine-induced contractions on rabbit aorta; (b) phenylephrine-induced contractions on rabbit saphenous artery; (c) U-46619-induced contractions on porcine coronary artery; (d) phenylephrine-induced contractions on canine femoral vein. The data presented represent means \pm s.e.mean, from five to 15 vessels per group.

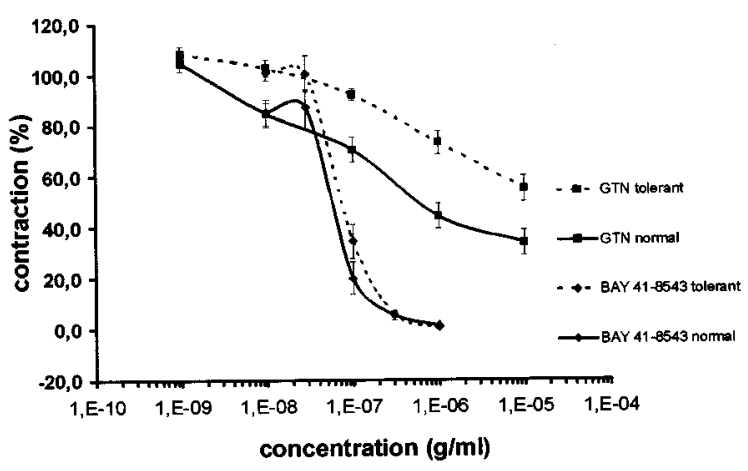

Figure 8 Vasorelaxing effects of BAY 41-8543 and GTN on rat aortic rings taken from normal and nitrate tolerant animals. Given are means of experiments with four rings per BAY 41-8543 group and 12 rings per GTN group.

compounds from YC1. In addition, YC-1 has recently been shown to act as a non-specific PDE inhibitor making interpretation of cell, tissue and in vivo experiments difficult (Galle et al., 1999; Friebe et al., 1998). In contrast, BAY 418543 is devoid of any PDE inhibitory activity.
The sGC is markedly activated by NO and to a lesser extent by CO (Hoenicka et al., 1999), and by PPIX, the ironfree heme precursor (Friebe et al., 1996). ODQ, a well-studied potent inhibitor of $\mathrm{sGC}$ is used to block the effects of the various stimulators on the purified enzyme (Garthwaite et al., 1995; Schrammel et al., 1996; Hoenicka et al., 1999; Feelisch et al., 1999). Here we studied the effects of BAY 41-8543 and NO on the stimulation of the highly purified sGC and the blocking effects of ODQ. BAY 41-8543 stimulates the recombinant $\mathrm{SGC}$ concentration dependently from $0.0001 \mu \mathrm{M}$ to $100 \mu \mathrm{M}$ with an effect of 2- to 92-fold to a level that would be expected to cause biologically important increases in cyclic GMP. In combination, BAY 41-8543 and NO synergize over a wide range of concentrations. Moreover ODQ completely blocked the sGC stimulation induced by BAY 41-8543 (Schrammel et al., 1996; Garthwaite et al., 1995).

The mechanism underlying NO-mediated sGC activation was elucidated when PPIX was found to cause enzyme activation with kinetics indistinguishable from NO itself. The close similarity in these interactions suggests that a common form of the activated enzyme is produced. Thus, binding of 


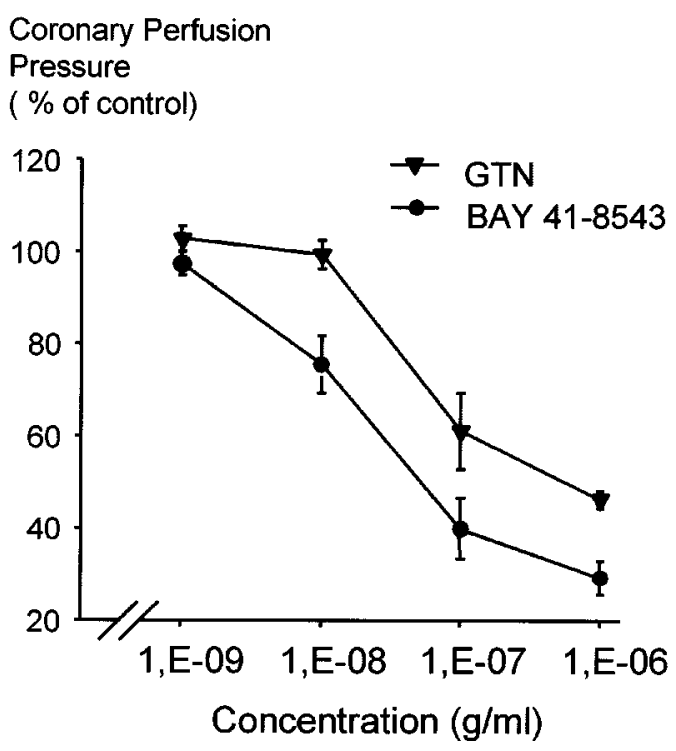

Figure 9 Effect of BAY 41-8543 and GTN on coronary perfusion pressure at the rat heart Langendorff preparation.

NO to the iron-heme results in the formation of a pentacoordinate iron-nitrosyl complex which breaks the bond to the axial $\mathrm{His}^{105}$ and elicits conformational changes leading to an increased catalytic activity (Ignarro, 1999; Zhao et al., 1998). Here we could also show that PPIX concentrationdependently stimulates the heme-free sGC and even synergizes with BAY 41-8543. These results show that activated enzyme molecules (either by NO or PPIX) are further stimulated by BAY 41-8543.

The binding of NO to the heme group can be visualized in heme spectra, which show a characteristic shift of the absorption maximum to lower wavelengths. To determine whether BAY 41-8543 directly interacts with the prosthetic heme group, we recorded the u.v.-visual spectra of the purified sGC under unstimulated and stimulated conditions (Hoenicka et al., 1999). NO elicited the characteristic shift of the Soret peak to lower wavelength, while the addition of BAY 41-8543 resulted in no change of the Soret band of neither the non-stimulated nor NO-stimulated enzyme. Therefore, unlike NO, BAY 41-8543 probably does not bind to the heme moiety of sGC. Because BAY 41-8543 showed no activity at the heme-free enzyme, we conclude that BAY 41-8543 activates sGC by an NO-independent, but hemedependent mechanism like YC-1 or BAY41-2272 (Hoenicka et al., 1999; Stasch et al., 2001).

For the determination of the binding site of this structural class a photoaffinity labelling study was performed (Stasch et al., 2001). Our studies suggest the existence of a new NO-independent regulatory site on sGC in the $\alpha_{1}$-subunit that modulates the catalytic rate and responsiveness towards the heme ligand. Recently it has been postulated that there is an intramolecular sixth ligand of the heme, which oscillates on and off the sixth coordinate, thereby conferring some sort of ligand specificity (i.e., NO and CO) (Hobbs et al., 1997; 2000). The binding of direct sGC stimulators to this site might block this intramolecular binding site and strengthen the binding of $\mathrm{NO}$ and $\mathrm{CO}$ to the enzyme. This model is compatible with
Human platelets: monoclonal anti-VASP- antibody

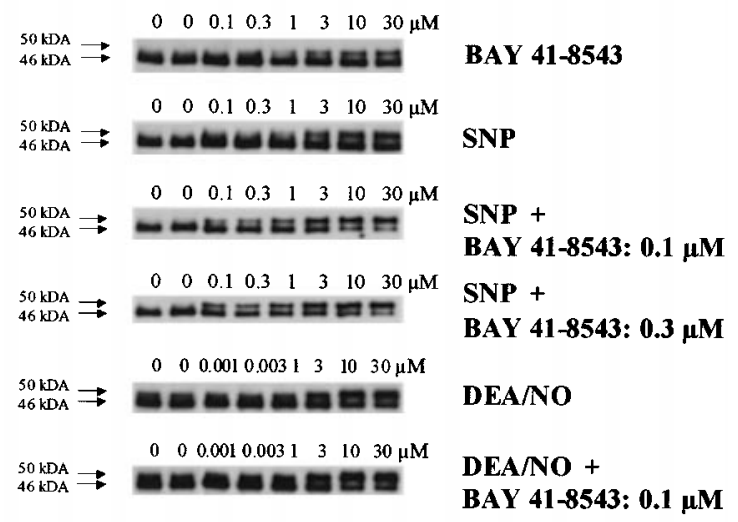

b

Human platelets: monoclonal anti-VASP-P239 antibody

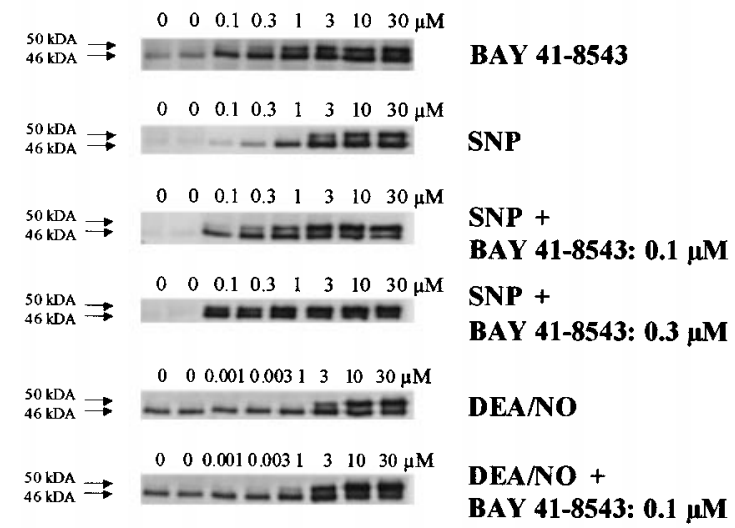

Figure 10 Concentration-dependent VASP-phosphorylation by the different types of sGC activators and by their combinations in intact human platelets. Washed human platelets (final $1.3 \times 10^{8}$ platelets $\mathrm{ml}^{-1}$ ) were incubated as indicated with BAY 418543, SNP and DEA/ $\mathrm{NO}$ at $37^{\circ} \mathrm{C}$. VASP-phosphorylation was analysed by immunoblots with either the monoclonal anti-VASP antibody ((a) $9 \times 10^{5}$ platelets per lane) to analyse the mobility shift, caused by $\operatorname{Ser}^{157}$ phosphorylation, or the monoclonal antibody $\left(16 \mathrm{C} 2\right.$, (b); $3.6 \times 10^{6}$ platelets per lane) to analyse $\operatorname{Ser}^{239}$ phosphorylation.

the sensitizing of the enzyme towards NO by this new class of stimulators.

We showed that BAY 41-8543 induced cyclic GMP formation in endothelial cells and that the synergistic effect with NO is also present. An interesting finding of the present report is the smaller increase in maximal cyclic GMP levels in intact endothelial cells induced by a combination of $\mathrm{NO}$ and BAY 41-8543 compared to the isolated enzyme. These results are in contrast to those reported recently with YC-1 (Schmidt et al., 2001). This discrepancy clearly indicates additional mechanisms mediating the effects of YC-1 in endothelial cells, like the inhibition of cyclic GMP hydrolysis by PDEs (Friebe et al., 1998; Galle et al., 1999), the stimulation of NO production through activation of eNOS (Wohlfahrt et al., 1999), the possibility of a physiological equilibrium between homo- and heterodimeric sGC complexes (Zabel et al., 1999) or the presence of a heat-labile factor that potentiates the effect of YC-1 and NO (Schmidt et al., 2001). In addition, endogenous NO formation induced by bradykinin synergizes with BAY 41- 
Table 2A Percentage of the the 50-kDa VASP species in human platelets after in vitro stimulation

\begin{tabular}{|c|c|c|c|c|c|c|c|}
\hline \multicolumn{8}{|c|}{$50-k D a V A S P(\%$ of total VASP; $n=3)$} \\
\hline $\begin{array}{l}\text { Conc. } \\
(\mu \mathrm{M})\end{array}$ & $\begin{array}{c}B A Y \\
41-8543\end{array}$ & $S N P$ & $\begin{array}{c}S N P+B A Y 41-8543 \\
(0.1 \mu \mathrm{M})\end{array}$ & $\begin{array}{c}S N P+B A Y 41-8543 \\
(0.3 \mu \mathrm{M})\end{array}$ & $\begin{array}{l}\text { Conc. } \\
(\mu \mathrm{M})\end{array}$ & $D E A / N O$ & $\begin{array}{c}D E A / N O+B A Y 41-8543 \\
(0.1 \mu \mathrm{M})\end{array}$ \\
\hline 0 & $10 \pm 5.0$ & & & & 0 & & \\
\hline 0.1 & $10 \pm 10$ & $7.7 \pm 7.7$ & $20.7 \pm 7.2$ & $32.0 \pm 4.4 *$ & 1 & $0 \pm 0$ & $6.8 \pm 3.8$ \\
\hline 0.3 & $8.5+8.5$ & $9.6+9.6$ & $26.8+7.5$ & $35.9 \pm 5.8 *$ & 3 & $2.3+2.3$ & $18.5+4.3$ \\
\hline 1 & $12.4 \pm 8.1$ & $18.9 \pm 9.7$ & $34.3 \pm 5.4 *$ & $48.0 \pm 5.5^{* *}$ & 10 & $8.5 \pm 4.9 *$ & $35.5 \pm 10.6^{*}$ \\
\hline 3 & $17.7+7.7$ & $36.8+8.0 * *$ & $55.9+5.5 * *$ & $63.1+5.4 * *$ & 30 & $20.2+8.2 *$ & $59.1+10.1 * *$ \\
\hline 10 & $26.6 \pm 6.6^{*}$ & $45.6 \pm 7.5^{* * *}$ & $68.8 \pm 1.0^{* *}$ & $71.3 \pm 2.6^{* * *}$ & 100 & $42.8 \pm 5.6^{* * *}$ & $75.9 \pm 7.4^{* * *}$ \\
\hline 30 & $33.1 \pm 5.5^{* * *}$ & $50.5 \pm 6.9^{* * *}$ & $74.7 \pm 2.2^{* *}$ & $81.8 \pm 1.0^{* * *}$ & 300 & $55.5 \pm 2.4 * * *$ & $84.0 \pm 8.6^{* * *}$ \\
\hline
\end{tabular}

Table 2B Cyclic GMP levels of human platelets after in vitro stimulation

\begin{tabular}{|c|c|c|c|c|c|c|c|}
\hline \multirow[b]{2}{*}{$\begin{array}{l}\text { Conc. } \\
(\mu \mathrm{M})\end{array}$} & \multicolumn{4}{|c|}{$\begin{array}{r}\text { cyclic GMP level (human platelets) } \\
\text { fmol cyclic GMP } \mathrm{ml}^{-1}\left(2 \times 10^{8} \text { platelets } m l^{-1}\right) \\
\text { (fold increase vs control) }\end{array}$} & \multicolumn{2}{|c|}{ \pm s.e.mean } & \multirow[b]{2}{*}{$\begin{array}{c}D E A / N O+B A Y 41-8543 \\
((0.1 \mu \mathrm{M})(n=4))\end{array}$} \\
\hline & $\begin{array}{c}B A Y 41-8543 \\
(n=5)\end{array}$ & $\begin{array}{l}S N P \\
(n=6)\end{array}$ & $\begin{array}{c}S N P+B A Y 41-8543 \\
((0.1 \mu \mathrm{M})(n=4))\end{array}$ & $\begin{array}{c}S N P+B A Y 41-8543 \\
((0.3 \mu \mathrm{M})(n=4))\end{array}$ & $\begin{array}{l}\text { Conc. } \\
\text { (nM) }\end{array}$ & $\begin{array}{c}D E A / N O \\
(n=4)\end{array}$ & \\
\hline 0 & $\begin{array}{c}134 \pm 15 \\
(1.0)\end{array}$ & & & & 0 & & \\
\hline 0.1 & $\begin{array}{c}228 \pm 38^{*} \\
(1.7)\end{array}$ & $\frac{194 \pm 33^{*}}{(1.5)}$ & $\begin{array}{c}616 \pm 42^{* * * *} \\
(4.6)\end{array}$ & $\begin{array}{c}1097 \pm 72^{* * * *} \\
(8.2)\end{array}$ & 1 & $\begin{array}{r}249 \pm 51 \\
(1.9)\end{array}$ & $\begin{array}{c}503 \pm 142 \\
(3.8)\end{array}$ \\
\hline 0.3 & $\frac{346 \pm 60 * *}{(2.6)}$ & $\begin{array}{c}204 \pm 27 * \\
(1.5)\end{array}$ & $\begin{array}{c}952 \pm 68 * * * \\
(7.1)\end{array}$ & $1517 \pm 114^{* * * *}$ & 3 & $\frac{314 \pm 45^{*}}{(2.3)}$ & $\begin{array}{c}758 \pm 216 \\
(5.7)\end{array}$ \\
\hline 1 & $718 \pm 192^{* *}$ & $\begin{array}{l}321 \pm 36^{* * * *} \\
(2.4)\end{array}$ & $\begin{array}{c}1559 \pm 100^{* * * *} \\
(11.6)\end{array}$ & $\begin{array}{c}2763 \pm 427 * * * \\
(20.6)\end{array}$ & 10 & $428 \pm 56^{* *}$ & $\begin{array}{c}1555 \pm 341 \\
(11.6)\end{array}$ \\
\hline 3 & $\begin{array}{c}1337 \pm 454^{* *} \\
(9.9)\end{array}$ & $\begin{array}{c}544 \pm 54^{* * * *} \\
(4.0)\end{array}$ & $\begin{array}{c}4501 \pm 798^{* * * *} \\
(33.6)\end{array}$ & $\begin{array}{c}12104 \pm 1655^{* * * *} \\
(90.3)\end{array}$ & 30 & $\begin{array}{c}856 \pm 138^{* * * *} \\
(6.4)\end{array}$ & $\begin{array}{c}4576 \pm 1251^{*} \\
(34.1)\end{array}$ \\
\hline 10 & $\begin{array}{c}2271 \pm 814^{* * *} \\
(16.9)\end{array}$ & $1013 \pm 115^{* * * *}$ & $\begin{array}{c}14986 \pm 2630^{* * * *} \\
(111.8)\end{array}$ & $\begin{array}{c}53719 \pm 9656^{* * * *} \\
(400.9)\end{array}$ & 100 & $\begin{array}{c}2164 \pm 205^{* * * *} \\
(16.1)\end{array}$ & $\begin{array}{c}15044 \pm 4042 * \\
(112.3)\end{array}$ \\
\hline 30 & $\begin{array}{c}3490 \pm 1086 * * \\
(26.0)\end{array}$ & $\begin{array}{c}1695 \pm 202^{* * * *} \\
(12.6)\end{array}$ & $\begin{array}{c}39404 \pm 4318 * * * \\
(294.1)\end{array}$ & $\begin{array}{c}63180 \pm 10675^{* * * *} \\
(471.5)\end{array}$ & 300 & $\begin{array}{c}5379 \pm 283^{* * * *} \\
(40.1)\end{array}$ & $\begin{array}{c}34813 \pm 463 * * * \\
(259.8)\end{array}$ \\
\hline
\end{tabular}

8543 over a wide range of concentrations with respect to cyclic GMP increase in endothelial cells.

Platelets are another intact cellular system in which synergistic effects between the different types of sGC stimulators could be verified. Moreover, platelets offer the opportunity to examine the effects of a cyclic GMP increase on a possible effector system, vasodilator-stimulated phosphoprotein. VASP (46-/50-kDa species) is one of the few established cyclic GMP-dependent PKG substrates and has been characterized as an important substrate of both cyclic AMP-dependent protein kinase and PKG in human platelets (Halbrügge et al., 1990; Smolenski et al., 1998). Because both the cyclic AMP and the cyclic GMP signaling cascades relax smooth muscle and inhibit platelet activation, it is speculated that VASP mediates some of these effects by modulating actin filament dynamics and integrin activation. VASP phosphorylation in response to cyclic nucleotide-regulating substances correlates with inhibition of platelet aggregation and with the inhibition of fibrinogen binding to the integrin $\alpha$ II $\beta 3$ of human platelets (Halbrügge et al., 1990; Horstrup et al., 1994). In agreement with these earlier studies, platelets of VASP-deficient mice presented with enhanced agonist-evoked activation and impaired cyclic nucleotide-caused inhibition indicate the important role of VASP as a link in signal transduction pathways in platelets (Aszódi et al., 1999;
Hauser et al., 1999). It is proposed that VASP phosphorylation closely correlates with sGC stimulation, platelet cyclic GMP increase and inhibition of platelet aggregation.

Therefore, the effect of BAY 41-8543 and NO donors on the phosphorylation status of VASP in human platelets was studied. sGC-dependent VASP phosphorylation (at $\operatorname{Ser}^{239}$ and $\operatorname{Ser}^{157}$ ) both by BAY 41-8543 and by NO donors was examined by gel electrophoresis with different antibodies to detect the mobility shift of VASP caused by $\mathrm{Ser}^{157}$ phosphorylation and to detect the PKG preferred phosphorylation site of VASP at Ser $^{239}$. BAY 41-8543 increased both VASP phosphorylation and cyclic GMP levels as did the NO donors DEA/NO and SNP. The combination of both types of stimulator induced a synergistic effect in both VASP phosphorylation and cyclic GMP increase. Thereby, BAY 418543 is on the one hand a direct potent stimulator of the cyclic GMP/PKG/VASP pathway and on the other hand synergizes with $\mathrm{NO}$, the physiological stimulator of $\mathrm{sGC}$. Recently we observed in human and rat platelets a concentration-dependent VASP phosphorylation and a cyclic GMP increase by YC-1 and synergistic effects between YC-1 and NO (Becker et al., 1999). However, the effect observed with BAY 41-8543 is distinctly more pronounced. BAY 418543 exerts its antiplatelet effect through the activation of the cyclic GMP/PKG/VASP pathway. Thus, BAY 41-8543 
potently inhibited collagen-induced platelet aggregation in washed human platelets and aggregation mediated by the thromboxane mimic U 46619, whereas thrombin or TRAP-6mediated aggregation was only weakly affected.

Due to activation of sGC leading to an intracellular cyclic GMP increase, BAY 41-8543 is a potent relaxing agent of saphenous artery, aorta, coronary artery and femoral vein with $\mathrm{IC}_{50}$ values in the $\mathrm{nM}$ range. In the rabbit aorta, BAY 41-8543 is about two orders of magnitude more potent than YC-1 (Mülsch et al., 1997; Straub et al., 2001). Moreover in the rat heart Langendorff preparation, BAY 41-8543 reduced the coronary perfusion pressure in a concentration-dependent manner with a maximal effect of about $70 \%$. A similar lowering of the coronary perfusion pressure was also observed with GTN, however this compound was about one order of magnitude less potent.

A major limitation of the use of organic nitrates in cardiovascular medicine is the development of tolerance, which has been attributed, in part, to a decrease in their metabolic activation in vascular smooth muscle cells (Elkayam, 1991; Parker, 1989). We used aortic rings from normal and nitrate-tolerant rats to study the hypothesis that sGC is not involved in nitrate tolerance and that the vasorelaxing effect of the sGC stimulator is the same under normal and tolerant conditions. Most notably, the vasor-

\section{References}

ASZÓDI, A., PFEIFER, A., AHMAD, M., GLAUNER, M., ZHOU, X.-H., NY, L., ANDERSSON, K.-E., KEHREL, B., OFFERMANNS, S. \& FÄSSLER, R. (1999). The vasodilator-stimulated phosphoprotein (VASP) is involved in cGMP- and cAMP-mediated inhibition of agonist-induced platelet aggregation, but is dispensable for smooth muscle function. EMBO J., 18, 37-48.

BECKER, E.M., SCHMIDT, P., SCHROEDER, H., WALTER, U., HOENICKA, M., GERZER, R. \& STASCH, J.-P. (2000). The vasodilator-stimulated phosphoprotein (VASP): mediator of YC-1 and nitric oxide effects in human and rat platelets. $J$. Cardiovasc. Pharmacol., 35, 390-397.

BECKER, E.M., WUNDER, F., KAST, R., ROBYR, C., HOENICKA, M., GERZER, R., SCHRÖDER, H. \& STASCH, J.-P. (1999). Generation and characterization of a stable soluble guanylate cyclase overexpressing CHO cell line. Nitric Oxide, 3, 55-66.

BORN, G.V. \& GROSS, M.J. (1963). The aggregation of blood platelets. J. Physiol., 168, $178-195$.

ELKAYAM, U. (1991). Tolerance to organic nitrates: evidence, mechanisms, clinical relevance, and strategies for prevention. Ann. Int. Med., 114, 667-677.

FEELISCH, M., KOTSONIS, P., SIEBE, J., CLEMENT, B. \& SCHMIDT, H.H.H.W. (1999). The soluble guanylyl cyclase inhibitor 1H$[1,2,4]$ oxadiazolo[4,3-a]quinoxalin-1-one is a nonselective heme protein inhibitor of nitric oxide synthase and other cytochrome $\mathrm{P}-450$ enzymes involved in nitric oxide donor bioactivation. Mol. Pharmacol., 56, 243-253.

FRIEBE, A., MÜLlERSHAUSEN, F., SMOLENSKI, A., WALTER, U., SCHULTZ, G. \& KOESLING, D. (1998). YC-1 potentiates nitric oxide- and carbon monoxide-induced cyclic GMP effects in human platelets. Mol. Pharmacol., 54, 962-967.

FRIEBE, A., SCHUlTZ, G. \& KOESLiNG, D. (1996). Sensitizing soluble guanylate cyclase to become a highly $\mathrm{CO}$-sensitive enzyme. EMBO J., 15, 6863-6868.

FURCHGOTT, R.F. (1999). Endothelium-derived relaxing factor: Discovery, early studies, and identification as nitric oxide (Nobel lecture). Angew. Chem.-Int. Ed. Engl., 38, 1870-1880.

GALLE, J., ZABEL, U., HÜBNER, U., HATZELMANN, A., WAGNER, B., WANNER, C. \& SCHMIDT, H.H.H.W. (1999). Effects of the soluble guanylate cyclase activator, $\mathrm{YC}-1$, on vascular tone, cyclic GMP levels and phosphodiesterase activity. $\mathrm{Br}$. J. Pharmacol., 127, 195-203. elaxation caused by BAY 41-8543 in aortic rings taken from normal and tolerant rats was the same. Obviously vascular superoxide anion formation which is believed as one of the consequences of nitrate tolerance does not affect the vasodilator activity of BAY 41-8543. Previously it was shown that basal and YC-1-stimulated sGC activity was slightly sensitive to inhibition by superoxide generated by xanthine/ xanthine oxidase, and was protected from this inhibition by superoxide dismutase (Mülsch et al., 1997). These observations indicate that BAY 41-8543 represents a new class of therapeutics probably be useful in overcoming the tolerance developing during sustained GTN therapy.

In summary, we present a potent new stimulator of $\mathrm{sGC}$, BAY 41-8543. Our data not only give a new insight in the regulation of sGC in vitro but also offer a novel therapeutic approach for treating cardiovascular diseases.

The authors would like to thank Dr U. Walter for providing us with the VASP antibodies, Dr E. Bischoff for performing the PDE assays, Mrs Y. Keim, Mrs A. Maile, B. Ducke, R.Hartkopf, Mrs E.M. Becker and A. Trabandt for their outstanding technical assistance, and Mrs A. Schmidt for preparing the manuscript.

Garthwaite, J., SOUtham, E., Boulton, C.L., NiElsen, E.B., SCHMIDT, K. \& MAYER, B. (1995). Potent and selective inhibition of nitric oxide-sensitive guanylyl cyclase by $1 \mathrm{H}[1,2,4]$ oxadiazolo[4,3-a]quinoxalin-1-one. Mol. Pharmacol., 48, 184-188.

HALBRÜGGE, M., FRIEDRICH, C., EIGENTHALER, M., SCHANZENBÄCHER, P. \& WALTER, U. (1990). Stoichometric and reversible phosphorylation of a $46-\mathrm{kDa}$ protein in in human platelets in response to cGMP- and cAMP-elevating vasodilators. J. Biol. Chem., 265, 3088-3093.

HAUSER, W., KNOBELOCH, K.-P., EIGENTHALER, M., GAMBARYAN, S., KRENN, V., GEIGER, J., GLAZOVA, M., ROHDE, E., HORAK, I., WALTER, U. \& ZIMMER, M. (1999). Megakaryocyte hyperplasia and enhanced agonist-induced platelet activation in vasodilator-stimulated phosphoprotein (VASP)-knock-out mice. Proc. Natl. Acad. Sci. U.S.A., 127, 526-528.

HOBBS, A.J. (1997). Soluble guanylate cyclase: the forgotten sibling. Trends Pharmacol. Sci., 18, 484-491.

HOBBS, A.J. (2000). Soluble guanylate cyclase. Emerg. Thera. Targets, 4, 735-749.

HOENICKA, M., BECKER, E.M., APELER, H., SIRICHOKE, T., SCHRÖDER, H., GERZER, R. \& STASCH, J.-P. (1999). Purified soluble guanylyl cyclase expressed in a baculovirus/Sf9 system: Stimulation by YC-1, NO and CO. J. Mol. Med., 77, 14-23.

HORSTRUP, K., JABLONKA, B., HÖNIG-LIEDL, P., JUST, M., KOCHSIEK, K. \& WALTER, U. (1994). Phosphorylation of focal adhesion vasodilator-stimulated phosphoprotein at Ser157 in intact human platelets correlates with fibrinogen receptor inhibition. Eur. J. Biochem., 225, 21-25.

IGNARRO, L.J. (1999). Nitric oxide: A unique endogenous signaling molecule in vascular biology (Nobel lecture). Angew. Chem.-Int. Ed. Engl., 38, $1882-1892$.

KO, F.N., WU, C.-C., KUO, S.-C., LEE, F.-Y.\& TENG, C.-M. (1994). YC1, a novel activator of platelet guanylate cyclase. Blood, 84, $4226-4233$

LAEMMLI, U.K. (1970). Cleavage of structural proteins during the assembly of the head of bacteriophage T4. Nature, 227, 680-685.

LINCOLN, T.M. (1989). Cyclic GMP and mechanism of vasodilation. Pharmac. Ther., 41, 479-502.

MONCADA, S. \& HIGGS, E.A. (1995). Molecular mechanisms and therapeutic strategies related to nitric oxide. FASEB J., 9, $1319-$ 1330. 
MONCADA, S., PALMER, R.M.J. \& HIGGS, E.A. (1991). Nitric oxide: physiology, pathophysiology, and pharmacology. Pharmacol. Rev., 43, $109-142$.

MÜLSCH, A., BAUERSACHS, J., SCHAEFER, A., STASCH, J.-P., KAST, R. \& BUSSE, R. (1997). Effect of YC-1, an NO-independent, superoxide-sensitive stimulator of soluble guanylyl cyclase, on smooth muscle responsiveness to nitrovasodilators. $\mathrm{Br} . \mathrm{J}$. Pharmacol., 120, 681-689.

MURAD, F. (1999). Discovery of some of the biological effects of nitric oxide and its role in cell signaling (Nobel lecture). Angew. Chem.-Int. Ed. Engl., 38, 1857-1868.

PARKER, J.O. (1989). Nitrate tolerance in angina pectoris. Cardiovasc. Drugs Ther., 2, $823-829$.

SCHMIDT, K., SCHRAMMEL, A., KOESLING, D. \& MAYER, B. (2001). Molecular mechanisms involved in the synergistic activation of soluble guanylate cyclase by $\mathrm{YC}-1$ and nitric oxide. Mol. Pharmacol., 59, 220-224.

SCHRAMMEL, A., BEHRENDS, S., SCHMIDT, K., KOESLING, D. \& MAYER, B. (1996). Characterization of $1 \mathrm{H}[1,2,4]$ oxadiazolo[4,3a]quinoxalin-1-one as a heme-site inhibitor of nitric oxidesensitive guanylyl cyclase. Mol. Pharmacol., 50, $1-5$.

SMOLENSKI, A., BACHMANN, C., REINHARD, K., HÖNIG-LIEDL, P., JARCHAU, T., HOSCHUETZKY, H. \& WALTER, U. (1998). Analysis and regulation of vasodilator-stimulated phosphoprotein serine 239 phosphorylation in vitro and in intact cells using a phosphospecific monoclonal antibody. J. Biol. Chem., 273, 20029-20035.

STASCH, J.-P., BECKER, E.M., ALONSO-ALIJA, C., APELER, H., DEMBOWSKY, K., FEURER, A., GERZER, R., MINUTH, T., PERZBORN, E., PLEIß, U., SCHROEDER, H., SCHROEDER, W., STAHL, E., STEINKE, W., STRAUB, A. \& SCHRAMM, M. (2001). NO-independent regulatory site on soluble guanylate cyclase. Nature, 410, 212-215.

STASCH, J.-P., DEMBOWSKY, K., PERZBORN, E., STAHL, E. \& SCHRAMM, M. (2002). Cardiovascular actions of a novel NOindependent guanylyl cyclase stimulator, BAY 41-8543: in vivo studies. Br. J. Pharmacol., 135, 333-343.

STRAUB, A., FEURER, A., ALONSO-ALIJA, C., STASCH, J.-P., PERZBORN, E., HÜTTER, J., DEMBOWSKY, K. \& STAHL, E. (1998). Substituted pyrazole derivatives condensed with six-membered heterocyclic rings. Publication No: WO 2,000,006,568 (2000) Chem. Abstr., 132, 122629.
STRAUB, A., STASCH, J.-P., ALONSO-ALIJA, C., BENET-BUCHHOLZ, J., DUCKE, B., FEURER, A. \& FÜRSTNER, C. (2001). NOindependent stimulators of soluble guanylate cyclase. Bioorg. Med. Chem. Lett., 11, $781-784$.

TOWBIN, H., STAEHLIN, T. \& GORDON, J. (1979). Electrophoretic transfer of proteins from polyacrylamide gels to nitrocellulose sheets: procedure and some applications. Proc. Natl. Acad. Sci. U.S.A., 76, $4350-4354$.

WEDEL, B.J. \& GARBERS, D.L. (1997). New insights on the functions of the guanylyl cyclase receptors. FEBS Letts., 410, 29-33.

WOHLFAHRT, P., MALINSKY, T., RUETTEN, H., SCHINDLER, U., LINZ, W., SCHOENAFINGER, K., STROBEL, H. \& WIEMER, G. (1999). Release of nitric oxide from endothelial cells stimulated by YC-1, an activator of soluble guanylate cyclase. $\mathrm{Br} . \mathrm{J}$. Pharmacol., 128, 1316-1322.

WU, C.C., KO, F.N. \& TENG, C.M. (1997). Inhibition of platelet adhesion to collagen by cGMP-elevating agents. Biochem. Biophys. Res. Commun., 231, 412-416.

WU, C.C., KO, F.-N., KUO, S.-C., LEE, F.Y.\& TENG, C.M. (1995). YC-1 inhibited human platelet aggregation through NO-independent activation of soluble guanylate cyclase. Br. J. Pharmacol., 116, $1973-1978$.

ZABEL, U., HAUSLER, C., WEEGER, M. \& SCHMIDT, H.H.H.W. (1999). Homodimerization of soluble guanylyl cyclase subunits. Dimerization analysis using a glutathione S-transferase affinity tag. J. Biol. Chem., 247, $18149-18152$.

ZHAO. Y, SCHELVIS, J.P.M., BABCOCK, G.T. \& MARLETTA, M.A. (1998). Identification of histidine 105 in the $\beta_{1}$ subunit of soluble guanylate cyclase as the heme proximal ligand. Biochemistry, 37, $4502-4509$.

ZHUO, M. \& HAWKINS, R.D. (1995). Long-term depression: a learning-related type of synaptic plasticity in mammalian central nervous system. Rev. Neurosci., 6, 259-277.

(Received June 5, 2001 Revised October 30, 2001 Accepted November 5, 2001) 